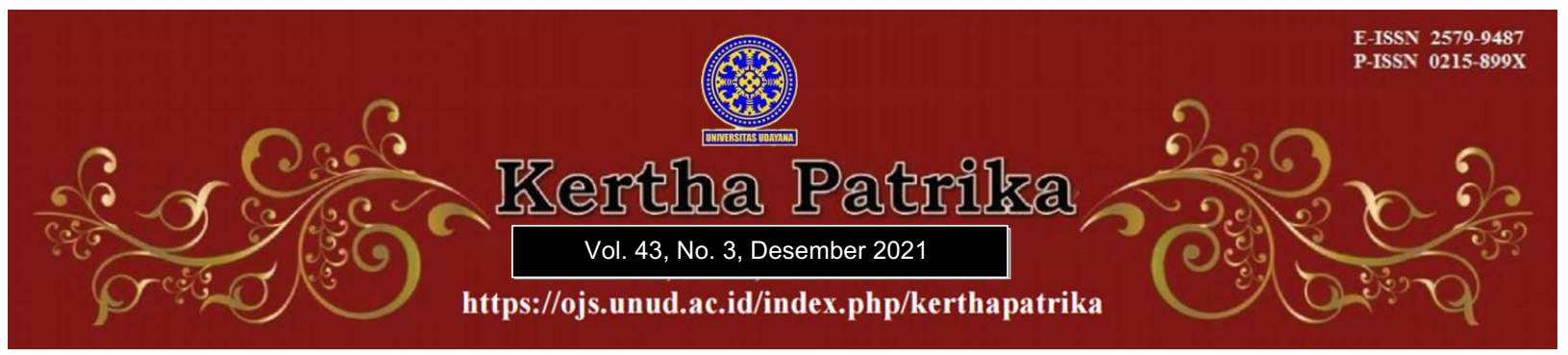

\title{
The Authority of Bali Governor in Regulating the Control of Corona Virus Disease 19
}

\author{
I Wayan Wiryawan, ${ }^{1}$ Putu Gede Arya Sumerta Yasa, ${ }^{2}$ Ibrahim R $^{3}$ \\ 1IKIP Saraswati Tabanan, E-mail: iwynwiryawan@gmail.com \\ 2 Fakultas Hukum Universitas Udayana, E-mail: arya.sumerthayasa@unud.ac.id \\ ${ }^{3}$ Fakultas Hukum Universitas Udayana, E-mail: mrprof.ibrahim@gmail.com
}

\begin{tabular}{l}
\hline Info Artikel \\
\hline Submitted : $12^{\text {th }}$ September 2021 \\
Accepted : $21^{\text {st }}$ December 2021 \\
Published : $28^{\text {th }}$ December 2021 \\
Keywords : \\
Bali's Governor's Authority, \\
Corona Virus Disease 19, \\
Pandemic, Deconcentration, Co- \\
administration tasks \\
Corresponding Author: \\
I Wayan Wiryawan, \\
E-mail: \\
iwynwiryawan@gmail.com \\
DOI : \\
10.24843/KP.2021.v43.i03.p03
\end{tabular}

\begin{abstract}
The Governor of Bali Province Regulation Number 46 of 2020 was formed on a delegation owned by the Governor of Bali. However, Governor Regulation includes fines and their application on the spot. This kind of authority to include fines in the form of money is problematic in the community and at the same time incurred a legal problem because it is related to the legal norms set forth in the governor's regulation. The purpose of this research was to analyze the authority of the Governor of Bali in regulating the control of Corona Virus Disease 19 and to analyze the form of control of this disease in the Province of Bali. This research employed normative legal research. The result of this study indicated that the authority of the Governor Bali in regulating the control of Corona Virus Disease 19 only regulates the control of Corona Virus Disease 2019 in Bali. The authority to control Corona Virus Disease 2019 in Bali remains with the Central Government, while the Governor of Bali is only given assistance tasks. Controlling the Corona Virus Disease 2019 in Bali is a concurrent affair of the Central Government. Therefore, the authority remains with the Central Government, not the Bali Provincial Government. The form of controlling the Corona Virus Disease 19 in the Province of Bali is carried out based on the principle of deconcentration. The implementation of this principle is carried out by delegating coadministration tasks to the Governor of Bali.
\end{abstract}

\section{Introduction}

The World Health Organization (WHO) has declared the status of a global pandemic and confirming that "Covid-19 is an international emergency, every hospital and clinic around the world is advised to be able to prepare themselves to treat patients with the disease even though no patients have been detected". ${ }^{1}$ Every hospital must prepare every

1 Zhahrina, A. (2020, January 31). WHO Umumkan Wabah Virus Corona Berstatus Darurat Global, Apa Artinya?. https://sains.kompas.com/read/2020/01/31/113000623/who-umumkanwabah-virus-corona-berstatus-darurat-global-apa-artinya?page=all (accessed,2020-10-29) 
needs related to this Covid-19 virus. The threat from the spread of the Covid-19 virus has an impact on the economic, social, cultural, security and welfare aspects of the community. ${ }^{2}$

In this emergency condition has causes people to be more aware of personal health and family health. The Bali Provincial Government through the Governor of Bali's Appeal Letter Regarding the Conditions of the Covid-19 Pandemic Number 215/Gugascovid19/VI/2020 emphasized that "our common problem in this condition, namely the COVID-19 pandemic that we are currently facing, is one that is fully We must live the spirit of kindness and sincerity, patience, fortitude and persistence, as well as paras paros, gilik saguluk, salunglung sabayantaka, none other than for the sake of our common interests and safety." Facing such conditions, we must not be bored in the slightest, there should be no feeling of boredom, there should be no feeling of despair, we must not blame each other, "sing dadi bengkung lan meboya".

With those appeal, its hopes that the Balinese people will remain enthusiastic in dealing with Covid-19 and can continuously control the Covid-19 virus to spread. The spread of the Covid-19 virus is very much felt by the people in Bali. Its spread is evidenced by the number of victims who died due to exposure to the Covid-19 virus.

Based on data obtained from the Provincial Government of Bali as of October 29, 2020, there were 11647 positive patients (11618 Indonesian citizens and 29 foreigners), 812 patients being treated (811 Indonesian citizens and 1 foreigner), 10453 patients who had recovered ( 10427 Indonesian citizens and 26 foreigners) and 382 patients who died (380 Indonesian citizens and 2 foreigners)".${ }^{3}$ Compared to other areas, Bali is one of the areas with the fewest patients who died.

The data above illustrates that transmission of the Covid-19 is very fast in Bali. This condition has an impact on all levels of the economic life of the people in Bali. This incident was caused by the policy of the Bali Provincial Government which limited community activities. All community activities are limited by the Bali Provincial Government. Furthermore, the regional government issued the Governor of Bali Province Regulation Number 46 of 2020 concerning the Implementation of Discipline and Law Enforcement of Health Protocols as an Effort for Prevention and Control of Corona Virus Disease 2019 in the New Order of Life (hereinafter, Governor Bali Regulation No 46/2020). Legislation in the Indonesian legal system based on its authority can be divided into statutory regulations established as attribution authority (mandate of the constitution) and also statutory regulations established as implementing orders (delegations) from higher regulations. This Governor Regulation is based on the Minister of Home Affairs Regulation Number 20 of 2020 concerning the Acceleration of Handling Corona Virus Disease 2019 in the Regional Government Environment (hereinafter Minister of Home Affairs Regulation No 20/2020). Meanwhile, the Minister of Home Affairs Regulation is based on Presidential Instruction Number 6 of 2020

2 Astariyani, N. L. G., \& Sudiarawan, K. A. (2021). Evaluasi Pengaturan Kebijakan Daerah Dalam Masa Pandemi Covid-19 Di Kota Denpasar. Abdi Insani, 8(1), 65-71. doi: https:// doi.org/10.29303/abdiinsani.v8i1.376

3 Press Release Satuan Tugas Penanganan Covid-19 Provinsi Bali. Update : 29 October 2020. https://infocorona.baliprov.go.id/ (accessed, 2020-10-30) 
concerning Discipline Improvement and Law Enforcement of Health Protocols in the Prevention and Control of Corona Virus Disease 2019 (Hereinafter Presidential Instruction No 6/2020) and Instruction of the Minister of Home Affairs Number 4 of 2020 concerning Technical Guidelines for Drafting Regional Head Regulations in the Framework of Implementing Discipline and Law Enforcement of Health Protocols as an Effort for Prevention and Control of Corona Virus Disease 2019 in the Regions (hereinafter Minister of Home Affairs No 4/2020). Therefore, Governor Regulation No. 46 of 2020 is an implementing regulation that was formed not based on the above law but through a Presidential Instruction and an Instruction from the Minister of Home Affairs which is an application of the Freies Emerssen principle. ${ }^{4}$

Juridically, the Governor of Bali was given a delegation by the President to make governor regulations in accordance with the local wisdom of the people in Bali. Regarding the determination of administrative sanctions, the Governor of Bali determines the sanctions in the form of fines in Article 11 of the Bali Governor Regulation No 46/ 2020 stipulating that: The administrative sanctions as referred to in paragraph (1), namely:

a. For individuals who travel and/or carry out activities to Bali, between regencies/cities in Bali and/or in places under the authority of the Provincial Government as referred to in Article 6 paragraph (2), in the form of:

1) postponement of the provision of administrative services in accordance with the authority of the Provincial Government; and/or

2) pay an administrative fine of Rp. 100,000 (One hundred thousand rupiah) for those who do not use masks when doing activities and doing activities outside the home.

b. For Business Actors, Managers, Operators or Persons in Charge of Public Places and Facilities as referred to in Article 6 paragraph (3):

1) pay an administrative fine of Rp. 1,000,000 (One Million Rupiah) which does not provide Covid-19 prevention facilities;

2) to be published in the mass media as Business Actors, Managers, Operators or Persons in Charge of Public Places and Facilities who do not comply with the Health Protocol; and/or

3) recommendations for the temporary suspension of business licenses to authorized officials/agencies".

The sanctions specified in Article 11 paragraph (2) are fines for those who do not use masks when doing activities outside the home and for business actors who do not provide public facilities or facilities, they are subject to a fine. The authority of the Governor of Bali to include fines in the form of money in this article is a polemic in the community and at the same time a legal problem because it is related to the legal norms set forth in the governor's regulation. The application of sanctions against the people of Bali follows a presidential instruction that empowers regional leaders to impose punishment, including administrative fines, as a deterrence to those who violate health

4 Devangga, I. G. M. S., Budiartha, I. N. P., \& Widiati, I. A. P. (2021). Keberlakuan Yuridis Peraturan Protokol Kesehatan di Provinsi Bali. Jurnal Interpretasi Hukum, 2(1), 163-167. doi: https://doi.org/10.22225/juinhum.2.1.3088.163-167. 
rules. ${ }^{5}$ This is certainly also in line with the function of law according to Roscoe Pound which in modern legal theory of sociological jurisprudence considers law as a social engineering process, but this must be accompanied by a factor of legal awareness so that it can run well. 6

Related to the sanctions applied, the Governor of Bali I Wayan Koster said that "sanctions in the form of fines directly imposed on the spot for individuals and business actors, managers, organizers or persons in charge of public places and facilities who are proven not to carry out their obligations in the governor's regulation".7 Thus, the fines in the form of money are directly applied throughout Bali, both for individuals and for business actors. The imposition of this fine is applied on the spot, meaning that the imposition of a fine is directly applied. In this case, the public must immediately pay the applied fine where the violation occurred. This legal event is the impact of the Bali Governor's policy in controlling the Corona Virus Disease-2019. At a press conference at the Bale Gajah Office House Complex, Jaya Sabha, Bali Governor I Wayan Koster said, "individuals, business actors, managers, organizers, person in charge of places and public facilities who are proven not to implement health protocols will be subject to administrative sanctions".8 This Governor Regulation also imposes sanctions on business actors and providers of public facilities. The imposition of sanctions is also applied directly at the scene. The Governor of Bali Province Regulation Number 46 of 2020 was formed on a delegation owned by the Governor of Bali. However, the Bali Governor Regulation Number 46 of 2020 includes fines and their application on the spot. Regarding to the description above, it's necessary to write a research about "The Authority of the Governor of Bali in Controlling Corona Virus Disease 19".

Regarding to the introduction above, this article tries to find out several legal problems that can be raised concerning to the authority of the Governor of Bali in regulating the control of Corona Virus Disease 19 including: 1. What is the authority of the Governor of Bali in regulating the control of Corona Virus Disease 19? 2. What is the form of controlling the Corona Virus Disease 19 in Bali Province?

The purpose of legal research is "to gain knowledge of the legal rules contained in a statutory regulation". This study aims to analyze the authority of the Governor of Bali in regulating the control of Corona Virus Disease 19 and to analyze the form of control of the Corona Virus Disease 19 in the Province of Bali.

The author assures that there is no element of plagiarism in this study. As evidence in the distinction between studies, there are similar scientific papers, including; a scientific paper with the title Harmonization of Authorities for Handling the Covid-19 Pandemic Between Central and Regional Governments by Siti Chadijah which raised the issue of

5 Yudiawan, I. D. G. H., \& Putra, I. K. T. A. (2021). Penerapan Sanksi Administratif Kepada Masyarakat Berdasarkan Peraturan Gubernur. Jurnal Komunikasi Hukum (JKH), 7(2), 728-735. doi: http://dx.doi.org/10.23887/jkh.v7i2.38000.

6 Wedha, Y. Y., Singadimedja, H. O., Nurcahyo, E., Rosidi, A., \& Awi, S. I. M. (2020). The handling of the pandemic Covid 19 in the consciousness of the legal community in Bali. International Journal of Science, Technology \& Management, 1(2), 55-61. doi: https:// doi.org/10.46729/ijstm.v1i2.12.

7 Tidak Pakai Masker, Denda Rp 100.000 Pemprov Bali Keluarkan Pergub Penerapan Disiplin Protokol Kesehatan Cegah Covid-19. https:/ / www.nusabali.com/berita /79912/tidak-pakaimasker-denda-rp-100000 (accessed, 2020-11-04) 
how to regulate authority between the central government and regional governments in dealing with the Covid-19 pandemic according to the provisions of laws and regulations. ${ }^{9}$ In addition, a scientific paper with the title Juridical Applicability of Health Protocol Regulations in the Province of Bali by I Gede Malik Satya Devangga, et al which raised the issue of how the position of the Governor of Bali Regulation Number 46 of 2020 concerning the Implementation of Discipline and Law Enforcement of Health Protocols as an Effort for Prevention and Control of Coronavirus Disease 2019 In the New Era of Life Order in the legal system in Indonesia and how is the validity of the Bali Governor Regulation Number 46 of 2020 in the system of legislation in Indonesia. ${ }^{10}$

\section{Research Method}

Legal research is "a process that's taken to find out in order to be able to answer the existing legal issues".11 This research used normative legal research. The relevance of this type of research is as an effort to solve problems from legal issues by analyzing the control arrangements for Corona Virus Disease 19 in Bali and analyzing the form of authority of the Governor of Bali in controlling Corona Virus Disease 19 in Bali. The research approach used in this journal was a statutory approach in the field of local government law, namely Law 9 of 2015 concerning the Second Amendment to Law 23 of 2014 concerning Regional Government, Minister of Home Affairs Regulation No 20/2020, Presidential Instruction Number 6/2020, and Governor of Bali Province Regulation Number 46/2020. In addition, it also uses a conceptual approach, namely the concept of authority, the concept of regional autonomy and the concept of legislation.

\section{Result and Discussions}

\subsection{The Authority of the Governor of Bali in Regulating the Control of Corona Virus Disease 19}

The Republic of Indonesia legal system has known that the Governor is located as an extension of the Central Government or known as deconcentration which in this case is subordinate to the central government. ${ }^{12}$ Based on Article 1 point 3 of Law Number 23 of 2014 concerning Regional Government, it is determined that the Regional Government is the head of the region as an element of the Regional Government organizer who leads the implementation of government affairs which are the authority of the autonomous region. This provision becomes the legal basis for the Governor of Bali to have the authority to carry out government affairs in his area. In this authority is attached an authority that is owned by the Governor of Bali. This authority is the basis for every implementation of government affair in Bali or in other words, with this authority, the Governor of Bali can organize government in Bali.

9 Chadijah, S. (2020). Harmonisasi Kewenangan Penanganan Pandemi Covid-19 Antara Pemerintah Pusat dan Daerah. E-journal Ilmu Hukum: Kertha Semaya 8(6). p. 858-856. https://ojs.unud.ac.id/index.php/kerthasemaya/ article/view/60854.

10 Devangga, I. G. M. S., Budiartha, I. N. P., \& Widiati, I. A. P. Op.Cit. 163-167.

11 Zainudin, A. (2009). Metode Penelitian Hukum. Jakarta: Sinar Grafika.

12 Goni, R. M. (2015). Kewenangan Gubernur Dalam Pembentukan Peraturan Daerahsebagai Implementasi Pemberlakuan Otonomi Daerah. Lex Administratum, 3(4). https://ejournal.unsrat.ac.id/index.php/administratum/article/view/8676/8240. 
Philosophically, the authority is based on power. Even in the context of authority, it is often identified with power. According to the Big Indonesian Dictionary (KBBI "Kamus Besar Bahasa Indonesia"), authority is "the power to make decisions, rule, and delegate responsibilities to others". Moreover, the Black's Law Dictionary define authority in governmental law as "Legal power; a right to command or to act; the right and power of public officers to require obedience to their orders lawfully issued in the scope of their public duties.". ${ }^{13}$ This definition provides an understanding that authority is closely related to power. This power certainly owned by the Regional Government of the Province of Bali. Power is frequently linked with authority, and the terms power and authority are frequently used interchangeably. Even though, power is frequently confused with authority. In most cases, power is exercised through a relationship in which one party rules and the other is governed..$^{14}$ Because the executive, legislature, and judiciary have "formal power," power has the same meaning as authority. Power, along with other aspects such as law, authority (authority), justice, honesty, intelligence, and morality, is a fundamental component of a country's administration of government. ${ }^{15}$

In the concept of constitutional law, authority or competence described as "rechtsmacht" (legal power). In public law, authority is related to power. ${ }^{16}$ There is a slight difference between authority (gezag) that is called formal power, power that comes from being granted by law or legislature. Meanwhile, competence (bevoegdheid) only concerns a certain "onderdeel" (part) of authority. The authority in controlling corona virus disease 19 by the Governor of Bali is commonly called competency or jurisdiction. Jurisdictionally, the Governor of Bali has the authority to regulate the control of the corona virus disease 19 in Bali. This authority is used in the formation of policies in the form of governor regulations, governor circulars and appeals to the governor of Bali.

In relation to the authority that mentioned above, Indroharto said "three kinds of authority are sourced from laws and regulations, namely attribution, delegation and mandate". 17 These three kinds of authority are those based on statutory regulations. The authority of the Governor of Bali in controlling corona virus disease 19 comes from Law 23 of 2014 concerning Regional Government, Minister of Home Affairs Regulation No 20 /2020, and Presidential Instruction No 6/2020. The President through the Presidential Instruction has given authority to the Governor of Bali in controlling Corona Virus Disease 19, especially in terms of imposing sanctions on people who violate the provisions of the health protocol. The sanctions are aimed at people who violate the implementation of health protocols. The targets of the application of sanctions in the prevention and control of Corona Virus Disease 19 are those carried out by individuals, business actors, managers, organizers, or persons in charge of public places and facilities. Individuals are required to wear masks when doing activities outside the home or traveling outside the house and also when gathering. Then for business actors are also required to provide facilities and infrastructure in order to prevent and control the Covid-19 disease such as providing a place to wash hands complete with hand sanitizer and seats that are far apart.

13 Black, H. C. (1968). Black's Law Dictionary: Definitions of the Terms and Phrases of American and English Jurisprudence Ancient and Modern. Revised Fourth Edition. Minnesota.

14 Budiarjo M. (1998). Dasar-Dasar Ilmu Politik. Jakarta: Gramedia Pustaka Utama.

15 Kantaprawira R. (1998). Hukum dan Kekuasaan. Yogyakarta: Prenada Media Group.

16 Hadjon, Philipus M. (1997). Tentang Wewenang. Yuridika, 5\&6 (XII).

17 HR Ridwan. (2008). Hukum Administrasi Negara. Jakarta: Raja Grafindo Persada. 
Based on the Presidential Instruction, the Governor of Bali is obliged to carry out the control of Corona Virus Disease 19. This implementation is carried out by making various policies in the form of a governor's regulation, circulars and appeals. The Presidential Instruction regulate that the Central Government has given the task to take care of controlling the Corona Virus Disease 19 in Bali. Because controlling the Corona Virus Disease 19 is a matter for the Central Government. The government affairs as regulated in Article 9 paragraph (1) consist of absolute government affairs, congruent government affairs and general government affairs. Absolute government affairs are fully under the authority of the Central Government, then congruent government affairs are government affairs which are divided and/or handed over between the Central Government and Provincial and Regency/City Regions, while general government affairs are under the authority of the President as head of government. Concurrent government affairs which are the authority of the regions consist of mandatory government affairs and optional government affairs. Government affairs that must be carried out by all regions are known as compulsory government affairs. Elective government affairs, on the other hand, are government affairs that must be carried out by the region in accordance with the region's capability. Local governments can classify mandatory government affairs into two categories: those connected to basic services and those not related to basic services.

The Central Government was in charge of controlling the spread of Corona Virus Disease 19 across the Republic of Indonesia's territory. It has accordance in norm that regulated in Article 13 paragraph (2) of Law No. 23 of 2004. Central Government affairs are carried out by involving all regional heads in Indonesia as representatives of the Central Government in the regions. In Law No. 23 of 2014 concerning Regional Government, the Central Government's affairs are called concurrent affairs of the Central Government to the Regional Government.

Article 19 paragraph (1) of this law stipulates that "Concurrent government affairs under the authority of the Central Government shall be carried out:

a. itself by the Central Government;

b. by delegating it to the governor as the representative of the Central Government or to the Vertical Agency in the Region based on the principle of Deconcentration; or

c. by assigning the Regions based on the principle of Co-Administration.

Referring to the provisions of this article, the control of Corona Virus Disease 19 in Bali is the authority of the Central Government. Thus, the authority to control Corona Virus Disease 19 remains with the Central Government (not with the Regional Government). The Central Government only delegated to the Governor of Bali as the representative of the Central Government in Bali. The delegation of concurrent affairs is based on the principle of deconcentration. In the Law on Regional Government, Article 1 point 9 regulate that deconcentration is the delegation of a portion of the Central Government's authority to the governor as the Central Government's representative, to vertical agencies in specific areas, and/or to the governor and regent/mayor in charge of government affairs general. Similar to that, the principle of deconcentration, according to Siswanto Sunamo is the delegation of authority in which the actual authority lies with the center, which involves the determination of policy strategies and the achievement of program activities given to governors of vertical agencies in the regions according to the general policy direction of the central government, while the financing sector remains 
the same implemented by the central government. 18 In order to control the Corona Virus Disease 19 in Bali, the provincial government only has the authority to control Corona Virus Disease 19. This arrangement is carried out by forming various policies. The authority to regulate the control of Corona Virus Disease 19 in Bali was delegated to the Governor of Bali. This delegation of authority does not mean that controlling Corona Virus Disease 19 in Bali is a concurrent business of the Bali Regional Government but remains a concurrent business of the Central Government, only in its implementation it is delegated to the Governor of Bali. Thus, the Governor of Bali does not have the authority to carry out concurrent affairs of the Central Government. The governor of Bali only has the right to regulate his own area. Such as regulating the control of Corona Virus Disease 19. The rights obtained by the Governor of Bali are derived from the principle of deconcentration in the implementation of regional autonomy. Thus, the Governor of Bali has the right to control Corona Virus Disease 19 which comes from the Central Government. Where there is a delegation of concurrent government affairs from the President as the head of government at the center to the Governor of Bali as the Head of the Regional Government of the Province of Bali. The implementation of controlling the Corona Virus Disease 19 is the responsibility of the Governor of Bali. So that the authority from this center is an authority that is burdened with responsibility from the Central Government to the Governor of Bali in controlling Corona Virus Disease 19 in Bali. This policy arrangement by the Regional Government of the Province of Bali is also the application of the principle of "salus populi suprema lex esto" which means the people's safeties is the most important law. If the local government does not do anything, it will certainly get an attack from the community who will demand a concrete action on the problems that occur so that it will become a burden for the local government if it is not implemented with fast steps. ${ }^{19}$ All policies created and implemented by regions are component of national policies. ${ }^{20}$

\subsection{The Form of Control of Corona Virus Disease 19 in Bali Province}

The form of the Governor of Bali's authority in controlling Corona Virus Disease 19 is not based on the authority of attribution, delegation or mandate, but on the government task of co-administration. This form of authority is given by the President directly to the Governor of Bali. The provision of this assistance task was carried out to accelerate the control of Corona Virus Disease 19 in Bali because Corona Virus Disease 19 is a national case. Thus, each regional head is given the task of assisting to accelerate the work of the Government in breaking the chain of the spread of Corona Virus Disease 19.

Theoretically, the task of co-administration (tugas pembantuan) is a reflection of the system and "procedures for assigning the Government to regions and/or villages, from the provincial government to the City and/or village, as well as from the City Government to the village to carry out government and development affairs accompanied by the obligation to report its implementation and accountable to the one

18 Hananto, U. D. (2011). Asas Desentralisasi dan Tugas Pembantuan dalam UU No. 32 Tahun 2004 tentang Pemerintahan Daerah. Masalah-Masalah Hukum, 40(2), 202-212. doi: https://doi.org/10.14710/mmh.40.2.2011.202-212.

19 Pratiwi, D. K. (2021). Inovasi Kebijakan Pemerintah Daerah dalam Penanganan Covid-19 di Indonesia. Amnesti Jurnal Hukum, 3(1), 37-52. doi: https:// doi.org/10.37729/amnesti.v3i1.929.

20 Chadijah, S., Suyadi, A., \& Tohadi, T. (2020). Tarik Menarik Kewenangan Pemerintah Pusat Dan Pemerintah Daerah Dalam Penanganan Pandemi Covid-19. Rechtsregel: Jurnal Ilmu Hukum, 3(2), 226-236. doi: http://dx.doi.org/10.32493/rjih.v3i2.8091. 
who gave the assignment". ${ }^{21}$ Then according to Koesoemah Atmadja, the task of monitoring (medebewind/zelfbestuur) makes it possible for the higher-level government/local government to ask for help from the lower-level regional government/local government in order to carry out regional household tasks or affairs. ${ }^{22}$ The implementation of medebewind, in local government, is a higher level central or regional affair and does not turn into a regional household affair. ${ }^{23} \mathrm{Co}$-administration tasks are carried out because not all the authorities and tasks of the Government can be carried out using the principles of decentralization or deconcentration principles. The provision of co-administration tasks is intended to improve the efficiency and effectiveness of government administration, development management, and public services.

Juridically, the co-administration task given by the President is based on Article 19 paragraph (1) letter c as mentioned above. The purpose of providing assistance tasks is to facilitate the implementation of tasks and the resolution of problems controlling the Corona Virus Disease 19, as well as assisting the administration of government and development for regions and villages. As with the Netherlands, the task of coadministration (medebewind) is different from regional autonomy. ${ }^{24}$ The coadministration tasks given by the Government to the Governor of Bali include some of the Government's tasks which, if carried out by the regions and/or traditional villages in Bali, will be more efficient and effective. The co-administration tasks given by the Bali Provincial Government as an autonomous region to Cities/Regencies and villages include some tasks from the Bali Province, including in the field of government that is cross-City/Regency and some government tasks in certain other fields, including some government tasks. which cannot or cannot be implemented by the City/Regency.

The Government's efforts to carry out control of Corona Virus Disease 19 which leads to public health are increasingly being accelerated. The delegation of authority for government affairs to autonomous regions to regulate and manage government affairs in a decentralized system is one of the efforts to accelerate the process of controlling Corona Virus Disease 19 in Bali. Health affairs which are decentralized to local governments provide an opportunity for provincial regions such as Bali to formulate policies to deal with the spread of Covid-19.25 One of the reasons is because the Regional Government, which is considered the closest and knows the situation in its area, should be able to determine its fate in handling the COVID-19 pandemic and not only depend on the central government. ${ }^{26}$ Based on Article 1 point 6 of Law Number 23 of 2014 concerning Regional Government, it is observed that Regional Autonomy is the right,

21 HR Ridwan. Op.Cit.

22 Mahanani, A. E. E. Urgensi Desentralisasi, Dekonsentrasi Dan Tugas Pembantuan Dalam Menjamin Keutuhan Negara Kesatuan Republik Indonesia. Res Publica, 1(2), 17-35. https://ejournal.undip.ac.id/index.php/mmh/article/view/10471.

23 Pitono, A. (2012). Asas Dekonsentrasi dan Asas Tugas Pembantuan dalam Penyelenggaraan Pemerintahan. Jurnal Kebijakan Publik, 2(2). https://jkp.ejournal.unri.ac.id/index.php/JKP /article/view/882/875

24 Cavalcanti, M. F., \& Terstegg, M. J. (2020). The Covid-19 emergency in the Netherlands: a constitutional law perspective. DPCE Online, 43(2). http://www.dpceonline.it/index.php /dpceonline/article/view/977.

25 Chadijah, S. (2020). Op.Cit.

26 Febriyanti, N. K. A., Astara, I. W. W., \& Arthanaya, I. W. (2021). Implemetasi Pengaturan Pemberian Bantuan Sosial dalam Era Pandemi COVID-19 di Desa Adat Kuta. Jurnal Preferensi Hukum, 2(2), 276-281. doi: https:// doi.org/10.22225/jph.2.2.3322.276-281 
authority and obligation of autonomous regions to regulate and manage their own Government Affairs and the interests of local communities in the system of the Unitary State of the Republic of Indonesia. In fact, in the implementation of regional autonomy, regional governments are an extension of the central government in which regional governments are given the freedom to regulate their regions in accordance with the provisions and regulations set by the central government so that on this basis the government has the right to the authority to regulate its own regions and is still supervised by the center government. ${ }^{27} \mathrm{Co}$-Administration is an assignment from the government to the regional and/or village government or other designations with the obligation to report and account for the implementation to the one who assigned the task. Funding in the context of co-administration after the assignment of the government through the State Ministry/Agency to the Regional Head (Governor/Regent/Mayor) at the expense of the State Budget. The law is also the legal basis for the authority obtained by the Governor of Bali in the formation of governor regulations.

In connection with controlling the Corona Disease 19 Virus, the Governor of Bali received a task co-administration from the Central Government. The co-administration task is a reflection of the assignment system that originates from the Central Government to regions and/or villages, from the Provincial Government to cities and/or villages, as well as from the City Government to villages to carry out government and development affairs accompanied by the obligation to report their implementation and account for them to the Central Government.

The task of co-administration of the control of the Corona Disease 19 Virus in Bali is carried out by the Regional Government of the Province of Bali. The provision of coadministration is carried out because not all government authorities and tasks can be carried out by the Central Government. The provision of co-administration tasks is intended to increase the efficiency and effectiveness of controlling the Corona Disease 19 Virus, include providing public services. Meanwhile, the purpose of providing assistance to control the Corona Disease 19 Virus in Bali is to facilitate the implementation of tasks and problem solving as well as assisting the administration of government. The co-administration tasks given by the Central Government to the Bali Provincial Government include some of the Central Government's tasks which, if its carried out by the Regional Government, it will be more efficient and effective.

The efforts of the Central Government to carry out the prevention and control of the Corona Disease 19 Virus are the assistance tasks of the Central Government. The provision of assistance tasks from the Central Government aims to accelerate the control of the Corona Virus Disease 19. The Provincial Government of Bali is given the task of assisting to prioritize the use of budget allocations for 2019 Corona Virus Disease control activities. In other words, the Central Government provides assistance tasks to the Governor of Bali as regional heads in terms of the use of regional budget allocations in handling Corona Virus Disease 2019.

The validity of this co-administration task to the Governor of Bali is based on the applicable laws and regulations. According to Indroharto, "in addition to containing meaning for the validity (legality) of every government action carried out by a State Administration Agency or Official, it also shows that government authority comes from

27 Ibid 
the applicable laws and regulations". 28 When viewed from the source of the authority to make policies obtained by the Governor of Bali, it is sourced from the Central Government which is based on the Law on Regional Government.

Based on Article 1 point 11 of the Law on Regional Government, it is determined that the task of co-administration is an assignments from central government to an autonomous area to carry out part of the government affairs under the central government's authority, or from the provincial government to a district/city region to carry out part of the government affairs under the province Region's authority. In connection with controlling the Corona Virus Disease 2019, the Governor of Bali received assistance from the Central Government. In the implementation of controlling the Corona Virus Disease 2019 in Bali, the Central Government as the party giving the task and the Governor of Bali as the party receiving the assistance task. All costs allocated for controlling Corona Virus Disease 2019 in Bali come from the Central Government. The Bali Provincial Government is required to report the use of the budget issued by the Central Government. In other words, the Provincial Government of Bali must be responsible for the use of these funds to the Central Government. Therefore, as with the concept of co-administration theory (medebewind), the policy form of controlling the Corona Virus Disease 2019 by the Governor of Bali is a matter for the central government and does not turn into a regional household affair. The Governor of Bali in this case is fully responsible to the central government.

\section{Conclusion}

Based on the discussion above, related to the authority of the Governor of Bali in controlling Corona Virus Disease 2019 it can be concluded that: 1.) The authority of the Governor of Bali in regulating the control of Corona Virus Disease 19 only regulates the control of Corona Virus Disease 2019 in Bali. The authority to control Corona Virus Disease 2019 in Bali remains with the Central Government. Meanwhile, the Governor of Bali was only given a co-administration task. Controlling the Corona Virus Disease 2019 in Bali is a concurrent business of the Central Government. So, the authority remains with the Central Government, not the Bali Provincial Government. 2.) The form of control of the Corona Virus Disease 19 in the Province of Bali is carried out based on the principle of deconcentration. The implementation of the principle of deconcentration is carried out by delegating assistance tasks to the Governor of Bali. In carrying out coadministration tasks from the Central Government, the Governor of Bali is responsible to the Central Government as the party giving the task.

\section{References}

\section{Books}

Black, H. C. (1968). Black's Law Dictionary: Definitions of the Terms and Phrases of American and English Jurisprudence Ancient and Modern. Revised Fourth Edition. Minnesota.

Budiarjo M. (1998). Dasar-Dasar Ilmu Politik. Jakarta: Gramedia Pustaka Utama.

HR Ridwan. (2008). Hukum Administrasi Negara. Jakarta: Raja Grafindo Persada.

28 Indroharto. (2000). Usaha Memahami Undang-Undang Tentang Peradilan Tata Usaha Negara: Buku I Beberapa Pengertian Dasar Hukum Tata Usaha Negara. Jakarta: Sinar Harapan 
Indroharto. (2000). Usaha Memahami Undang-Undang Tentang Peradilan Tata Usaha Negara: Buku I Beberapa Pengertian Dasar Hukum Tata Usaha Negara. Jakarta: Sinar Harapan Kantaprawira R. (1998). Hukum dan Kekuasaan. Yogyakarta: Prenada Media Group.

Zainudin, A. (2009). Metode Penelitian Hukum. Jakarta: Sinar Grafika.

\section{Journals}

Astariyani, N. L. G., \& Sudiarawan, K. A. (2021). Evaluasi Pengaturan Kebijakan Daerah Dalam Masa Pandemi Covid-19 Di Kota Denpasar. Abdi Insani, 8(1), 65-71. doi: https:/ / doi.org/10.29303/abdiinsani.v8i1.376

Cavalcanti, M. F., \& Terstegg, M. J. (2020). The Covid-19 emergency in the Netherlands: a constitutional law perspective. DPCE Online, 43(2). http://www.dpceonline.it/ index.php/dpceonline/article/view/977.

Chadijah, S. (2020). Harmonisasi Kewenangan Penanganan Pandemi Covid-19 Antara Pemerintah Pusat dan Daerah. E-journal Ilmu Hukum: Kertha Semaya 8(6). p. 858856. https://ojs.unud.ac.id/index.php/kerthasemaya/ article/view/60854.

Chadijah, S., Suyadi, A., \& Tohadi, T. (2020). Tarik Menarik Kewenangan Pemerintah Pusat Dan Pemerintah Daerah Dalam Penanganan Pandemi Covid-19. Rechtsregel: Jurnal Ilmu Hukum,3(2), 226-236. doi: http:// dx.doi.org/10.32493/rjih.v3i2.8091.

Devangga, I. G. M. S., Budiartha, I. N. P., \& Widiati, I. A. P. (2021). Keberlakuan Yuridis Peraturan Protokol Kesehatan di Provinsi Bali. Jurnal Interpretasi Hukum, 2(1), 163167. doi: https://doi.org/10.22225/juinhum.2.1.3088.163-167.

Febriyanti, N. K. A., Astara, I. W. W., \& Arthanaya, I. W. (2021). Implemetasi Pengaturan Pemberian Bantuan Sosial dalam Era Pandemi COVID-19 di Desa Adat Kuta. Jurnal Preferensi Hukum,2(2), 276-281. doi: https://doi.org/10.22225/jph.2.2.3322.276-281

Goni, R. M. (2015). Kewenangan Gubernur Dalam Pembentukan Peraturan Daerahsebagai Implementasi Pemberlakuan Otonomi Daerah. Lex Administratum, 3(4).https:/ / ejournal.unsrat.ac.id/index.php/administratum/arti cle/view/8676/8240.

Hadjon, Philipus M. (1997). Tentang Wewenang. Yuridika, 5\&6 (XII).

Hananto, U. D. (2011). Asas Desentralisasi dan Tugas Pembantuan dalam UU No. 32 Tahun 2004 tentang Pemerintahan Daerah. Masalah-Masalah Hukum, 40(2), 202212. doi: https://doi.org/https://doi.org/10.14710/mmh.40.2.2011.202-212.

Mahanani, A. E. E. (2017). Urgensi Desentralisasi, Dekonsentrasi Dan Tugas Pembantuan Dalam Menjamin Keutuhan Negara Kesatuan Republik Indonesia. Res Publica, 1(2),17-35. https:/ / ejournal.undip.ac.id/index.php/mmh/ article/ view/10471.

Pratiwi, D. K. (2021). Inovasi Kebijakan Pemerintah Daerah dalam Penanganan Covid19 di Indonesia. Amnesti Jurnal Hukum,3(1), 37-52. doi: https:/ / doi.org/10.37729/amnesti.v3i1.929. 
Pitono, A. (2012). Asas Dekonsentrasi dan Asas Tugas Pembantuan dalam Penyelenggaraan Pemerintahan. Jurnal Kebijakan Publik, 2(2). https://jkp.ejournal.unri.ac.id/index.php/JKP/article/view/882/875

Wedha, Y. Y., Singadimedja, H. O., Nurcahyo, E., Rosidi, A., \& Awi, S. I. M. (2020). The handling of the pandemic Covid 19 in the consciousness of the legal community in Bali. International Journal of Science, Technology \& Management, 1(2), 55-61. doi: https://doi.org/10.46729/ijstm.v1i2.12.

Yudiawan, I. D. G. H., \& Putra, I. K. T. A. (2021). Penerapan Sanksi Administratif Kepada Masyarakat Berdasarkan Peraturan Gubernur. Jurnal Komunikasi Hukum (JKH), 7(2), 728-735. doi: http://dx.doi.org/10.23887/jkh.v7i2.38000.

\section{Online/World Wide Web}

Press Release Satuan Tugas Penanganan Covid-19 Provinsi Bali. Update : 29 October 2020. https://infocorona.baliprov.go.id/ (accessed, 2020-10-30).

Tidak Pakai Masker, Denda Rp 100.000 Pemprov Bali Keluarkan Pergub Penerapan Disiplin Protokol Kesehatan Cegah Covid-19. https://www.nusabali.com/berita /79912/tidak-pakai-masker-denda-rp-100000 (accessed, 2020-11-04).

Zhahrina, A. (2020, January 31) WHO Umumkan Wabah Virus Corona Berstatus Darurat Global, Apa Artinya?. https://sains.kompas.com/read/2020/01/31/ 113000623/who-umumkan-wabah-virus-corona-berstatus-darurat-global-apaartinya?page=all (accessed,2020-10-29).

\section{$\underline{\text { Laws/Regulations }}$}

Law Number 23 of 2014 concerning Regional Government

Regulation of the Governor of Bali Province Number 46 of 2020 concerning the Implementation of Discipline and Law Enforcement of Health Protocols as an Effort for Prevention and Control of Corona Virus Disease 2019 in the New Order of Life.

Presidential Instruction Number 6 of 2020 concerning Improvement of Discipline and Law Enforcement of Health Protocols in the Prevention and Control of Corona Virus Disease 2019.

Regulation of the Minister of Home Affairs Number 20 of 2020 concerning the Acceleration of Handling Corona Virus Disease 2019 in Regional Governments.

Instruction of the Minister of Home Affairs Number 4 of 2020 concerning Technical Guidelines for Drafting Regional Head Regulations in the Context of Implementing Discipline and Law Enforcement of Health Protocols as an Effort for Prevention and Control of Corona Virus Disease 2019 in the Regions 